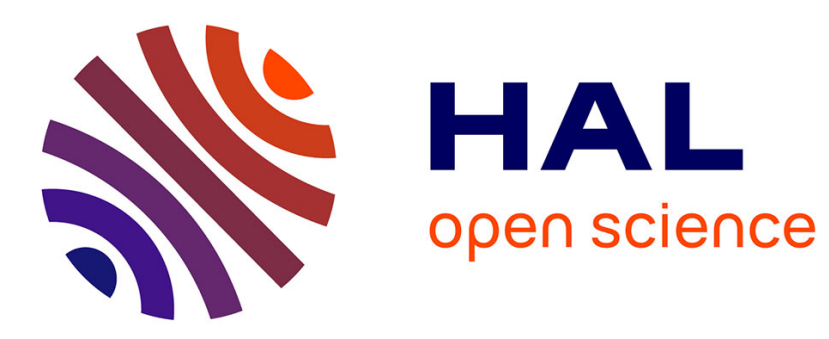

\title{
Effect of osmotic pressure on prolactin release in rainbow trout: in vitro studies
}

Fabienne Gonnet, Patrick Prunet, M.C. Tonon, P. Dubourg, Olivier Kah, Hubert, Joseph, Maurice Vaudry

\section{- To cite this version:}

Fabienne Gonnet, Patrick Prunet, M.C. Tonon, P. Dubourg, Olivier Kah, et al.. Effect of osmotic pressure on prolactin release in rainbow trout: in vitro studies. General and Comparative Endocrinology, 1988, 69, pp.252-261. 10.1016/0016-6480(88)90013-5 . hal-02728185

\section{HAL Id: hal-02728185 \\ https://hal.inrae.fr/hal-02728185}

Submitted on 2 Jun 2020

HAL is a multi-disciplinary open access archive for the deposit and dissemination of scientific research documents, whether they are published or not. The documents may come from teaching and research institutions in France or abroad, or from public or private research centers.
L'archive ouverte pluridisciplinaire HAL, est destinée au dépôt et à la diffusion de documents scientifiques de niveau recherche, publiés ou non, émanant des établissements d'enseignement et de recherche français ou étrangers, des laboratoires publics ou privés. 


\title{
Effect of Osmotic Pressure on Prolactin Release in Rainbow Trout: in Vitro Studies
}

\author{
F. Gonnet, P. Prunet,${ }^{1}$ M. C. Tonon,${ }^{*}$ P. Dubourg,, O. Kah $\dagger$ and H. Vaudry* \\ Laboratoire de Physiologie des Poissons, INRA, Campus de Beaulieu, 35042 Rennes Cédex; *Groupe de \\ Recherche en Endocrinologie Moléculaire, UA CNRS 650, Unité alliée à l'INSERM, Faculté des Sciences, \\ Université de Rouen, 76160 Mont-St-Aignan; and †Laboratoire de Physiologie des Interactions Cellulaires, \\ Université de Bordeaux I, Av des Facultés, 33405 Talence Cédex, France
}

Accepted August 28, 1987

\begin{abstract}
To investigate a possible effect of osmotic pressure on prolactin (PRL) release in rainbow trout, we developed a technique for in vitro perifusion of trout pituitaries. Changes in osmotic pressure similar to those observed in fish plasma during transfer experiments did not induce significant modifications of PRL release. In contrast, high-amplitude variation of osmotic pressure resulted in clear modifications of PRL secretion: hyperosmotic medium caused a reduction in PRL release, while infusion of hyposmotic medium induced a transitory increase in PRL release. By using different concentrations of mannitol, we found that the modifications of prolactin secretion could not be ascribed to alterations of the ionic composition of the medium but actually resulted from variations in the osmotic pressure of the incubation medium. In further experiments osmotic pressure was decreased from 300 to $220 \mathrm{mOsm} / \mathrm{kg}$ or from 400 to $300 \mathrm{mOsm} / \mathrm{kg}$; a similar transitory increase in PRL release was observed. Measurement of gonadotropin $(\mathrm{GtH})$ in the perifusion effluent medium showed that PRL and GtH secretion followed similar patterns. Thus, our results suggest a possible mechanical effect of wide changes in osmotic pressure on pituitary cell membranes. These data indicate that the rainbow trout differs notably from nonsalmonid teleost species thus far studied in the lack of sensitivity of its PRL cells to osmotic pressure. (1988 Academic Press. Inc.
\end{abstract}

In some teleost fish, prolactin (PRL) secretion appears to be controlled through two different mechanisms: neuroendocrine pathways involving hypothalamic aminergic and peptidergic neurons and a systemic pathway (changes in plasma osmotic pressure) often associated with changes in ambient salinity (see reviews by Clarke and Bern, 1980; Ball, 1981; Bern, 1983; Specker et al., 1984). Numerous histological studies have shown that transfer of teleosts to environments of altered salinity is associated with morphological changes in the PRL cells which appear more active in fresh water (FW) than in seawater (SW) (cf., e.g., Dharmamba and Nishioka, 1968; Abra-

\footnotetext{
${ }^{1}$ To whom requests for reprints should be addressed.
}

ham, 1971; Nagahama et al., 1973, 1975, 1977; Dubourg et al., 1980; Wendelaar Bonga and Van der Meij, 1980; Olivereau et al., 1981). Experiments with fish bearing autografted pituitaries suggest that in goldfish, goby, and tilapia, PRL cells may be controlled directly by plasma osmotic pressure, with higher osmolarity being inhibitory (Leatherland and Ensor, 1973; Nagahama et al., 1974, 1975). These results have been confirmed using incubated or perifused pituitary fragments in vitro (Ingleton et al., 1973; Nagahama et al., 1975; Wigham et al., 1977; Grau et al., 1981, 1986, 1987; Batten et al., 1983); however, further experiments with Oreochromis mossambicus transferred to environments of high osmolarity or with high $\mathrm{Ca}^{2+}$ concentrations indicate that plasma osmolarity 
may not be an important regulatory factor for PRL cells (Wendelaar Bonga et al., 1985). In salmonids, several studies reported changes in prolactin ccll activity in salmon acclimated to hyper- or hyposmotic medium (Leatherland and McKeown, 1974; Leatherland and Lin, 1975; Nagahama et al., 1977); while others could not detect any effect of salinity on prolactin cells (Cook and Van Overbeeke, 1969; Mckeown and Leatherland, 1973). Moreover, no clear change in PRL release occurred in low- or high-sodium medium in vitro, although sodium has been reported to affect the production of newly synthesized PRL (Baker and Ingleton, 1975).

These contradictory results in salmonids led us to reinvestigate more precisely, in rainbow trout, the possible effect of osmotic pressure on PRL release by pituitary fragments. For this purpose we developed a technique for in vitro perifusion associated with a specific radioimmunoassay (RIA) for salmon PRL, to study the kinetics of PRL secretion by the trout pituitary. Our results indicate that osmotic pressure does not seem to be an important factor controlling PRL release in rainbow trout.

\section{MATERIALS AND METHODS}

Animals. Immature rainbow trout, Salmo gairdneri $(50-100 \mathrm{~g})$, were kept in recirculating tap water at $13 \pm$ $1^{\circ}$ under natural photoperiod. All fish used in our experiments were of similar age (1 year old). Pituitaries were removed after decapitation, between 8 and 9 AM. For PRL experiments the rostral pars distalis (RPD) was dissected under a dissecting microscope; however, the RPD was partially contaminated with the proximal pars distalis (PPD) and the neurohypophysis $(\mathrm{NH})$. For experiments in which gonadotropin (GtH) was measured all the pars distalis was used and this material was partially contaminated with the $\mathrm{NH}$. Pituitary fragments were preincubated for $10 \mathrm{~min}$ in Ringer solution ( $\mathrm{NaCl} 140 \mathrm{mM}, \mathrm{KCl} 2 \mathrm{mM}, \mathrm{CaCl}_{2} 2$ $\mathrm{m} M$. Hepes $15 \mathrm{mM}$ ) gassed with $95 \% \mathrm{O}_{2}-5 \% \mathrm{CO}_{2}$. Immediately before use, the Ringer solution was supplemented with $2.5 \mathrm{~g} /$ liter glucose and $0.3 \mathrm{~g} /$ liter bovine serum albumin (fraction V, Sigma) and the $\mathrm{pH}$ adjusted to 7.4. The osmotic pressure was 300 $\mathrm{mOsm} / \mathrm{kg}$.
Perifusion. The perifusion system, previously described by Tonon et al. (1980), was composed of siliconized glass columns $(0.9 \times 12 \mathrm{~cm})$ delimited by Teflon plungers. The volume of the chamber was $1.5 \mathrm{ml}$. The rostral lobes (usually 3-5 per column) were suspended in a Bio-Gel P2 support matrix and perifused with the medium described above at constant flow rate $(0.2 \mathrm{ml} / \mathrm{min})$ and temperature $\left(15 . \pm 1^{\circ}\right)$. Samples $(1.5$ $\mathrm{ml}$ ) were collected at 7.5-min intervals; hormone levels were measured on the day of perifusion, or samples were frozen at $-20^{\circ}$ until assay. Unless specified, osmotic pressure changes were produced by addition of mannitol (Sigma) to a Ringer solution containing 112 $\mathrm{m} M \mathrm{NaCl}$ until the desired osmotic pressure was attained. Osmolarity was determined with a Roebling osmometer.

Radioimmunoassay. PRL secreted from rainbow trout pituitaries was determined using a PRL salmon RIA according to the technique described by Hirano et al. (1985) and modified by Prunet et al. (1985). This RIA has been demonstrated to be specific for measurement of PRL in rainbow trout as the absence of crossreactivity with plasma from hypophysectomized rainbow trout and parallelism between the standard curve (chinook PRL) and dilution curves of rainbow trout plasma (Hirano et al., 1985; Prunet et al., 1985). Moreover, serial dilution of perifusate gave inhibition curves parallel to those of chinook PRL standard. Routinely the volume of perifusate assayed was 150 $\mu \mathrm{l}$. The sensitivity of the assay was estimated to be 0.4 $\mathrm{ng} / \mathrm{ml}$, and the intraassay coefficient of variation was $4.7 \%$ for $11 \mathrm{ng} / \mathrm{ml}(n=10)$. GtH levels in the perifusate were determined in $20-\mu$ laliquots as described by Breton et al. (1978).

Calculation. Unless specified, each perifusion pattern was calculated as the mean amount of PRL or $\mathrm{GtH}$ released in three independent experiments. Baseline secretion was achieved within an hour: accordingly, all tubes collected during the first hour were discarded. As basal level could change from one column to the other, hormone secretion was expressed as a percentage of the basal level. The basal level (indicated as $100 \%$ ) was calculated as the mean three samples just preceding the first change in osmotic pressure in each experiment.

Electron microscope studies. Two groups of pituitaries were examined to determine the possible ultrastructural changes occurring during perifusion. Control pituitaries were dissected out and immediately fixed by immersion in $6.25 \%$ glutaraldehyde (Soerensen buffer, $0.015 M, \mathrm{pH} 7.4$ ) according to Dubourg et al. (1983). After $15 \mathrm{~min}$, the pituitaries were rinsed in Soerensen buffer, postfixed in $1 \%$ osmium tetroxide (Michaelis buffer, pH 7.4), dehydrated, and embedded in Epon. The experimental pituitaries were perifused for $7 \mathrm{hr}$ under the conditions described above. Then the fixative solution was introduced into the perifusion 
chamber and the pituitaries were removed from the chamber and postfixed as in the control group.

\section{RESULTS}

\section{Validation of the Perifusion Technique}

Figure 1 shows typical patterns of PRL release during a 6 -hr perifusion at three different osmotic pressures. An initial decrease was observed when the pituitaries were perifused with hyposmotic ( 220 $\mathrm{mOsm} / \mathrm{kg})$, isosmotic $(300 \mathrm{mOsm} / \mathrm{kg})$, and hyperosmotic ( $400 \mathrm{mOsm} / \mathrm{kg}$ ) Ringer solution; however, within $1 \mathrm{hr}$, the secretion rate reached its basal level and remained stable throughout the experiments. Since the basal release varied from one column to the other, values in all subsequent experiments were expressed as percentages of the spontaneous secretion rate. 'The total amounts of PRL secreted during 6-hr perifusions have been measured in three independent experiments. The total PRL released during the perifusion was $1.8 \pm 0.29$ $\mu \mathrm{g} / \mathrm{gland}$, while the tissue PRL content al the end of the experiment was $4.19 \pm 0.66$ $\mu \mathrm{g} / \mathrm{gland}$. The ultrastructural characteristics of perifused pituitaries are shown in Fig. 2. The PRL cells of rainbow trout are easily recognized owing to their follicular arrangement. In perifused glands, blood cells still present in the capillaries were ob-

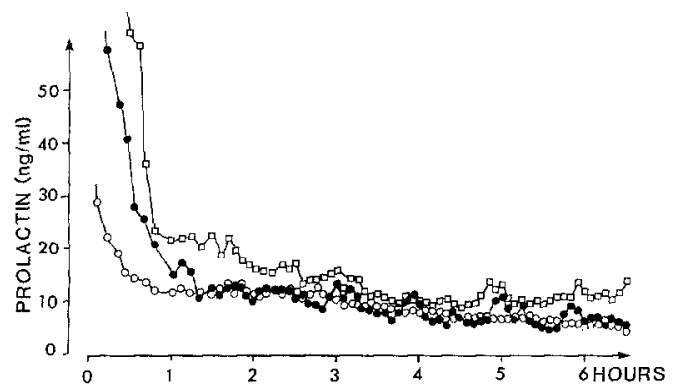

FIG. 1. Comparison between the PRL secretion patterns of trout rostral pars distalis perifused for $6 \mathrm{hr}$ at three different osmotic pressures. $\bigcup$, Isosmotic Ringer solution (300 $\mathrm{mOsm} / \mathrm{kg})$; , hyperosmotic Ringer solution $(400 \mathrm{mOsm} / \mathrm{kg}) ; \square$, hyposmotic Ringer solution (220 $\mathrm{mOsm} / \mathrm{kg})$. served, and their ultrastructure did not appear to be affected by the experimental procedure. In addition, mitosis was occasionally observed in perifused glands as in controls. In both control and perifused tissues, cells exhibited a marked polarity with the nucleus located at the basal pole. As compared with controls (Fig. 2a) the fine structure of perifused PRL cells (Fig. 2b) showed a reduction in cytoplasmic vacuoles; however, these differences were minor and after a 6-hr perifusion, PRL cells were still loaded with secretory granules as were control cells. It thus appears that the viability of PRL cells was not altered during perifusion.

\section{In Vitro Effects of Osmotic Pressure on PRL Release}

The effects of changes in osmotic pressure on PRL release in vitro were initially studied via alterations in $\mathrm{NaCl}$ concentrations. Stepwise increases in $\mathrm{Na}^{+}$concentration from $112 \mathrm{~m} M(220 \mathrm{mOsm} / \mathrm{kg})$ to 130 $\mathrm{m} M(260 \mathrm{mOsm} / \mathrm{kg})$ and then to $170 \mathrm{mM}$ $(344 \mathrm{mOsm} / \mathrm{kg})$ did not induce significant changes in basal PRL release (Fig. 3). In another experiment (Fig. 4) perifused pituitary fragments were successively exposed to $160 \mathrm{mM} \mathrm{Na}{ }^{+}(310 \mathrm{mOsm} / \mathrm{kg})$ and 200 $\mathrm{mM} \mathrm{Na}{ }^{+}(380 \mathrm{mOsm} / \mathrm{kg})$ without major modifications of PRL release; the tendency toward a decrease with high-osmoticpressure medium was not significant.

These first results led us to investigate the effects of high-amplitude variation of osmotic pressure. After exposure to isosmotic medium for half an hour (140 $\mathrm{m} M$ $\mathrm{Na}^{+}, 290 \mathrm{mOsm} / \mathrm{kg}$ ), the medium was switched to hyperosmotic medium (400 $\mathrm{mOsm} / \mathrm{kg}$ ) which caused an immediate decrease in PRL release (30.9 $\pm 4.6 \%$ ). This decrease was maintained during the whole period (1 hr) of hyperosmolar perifusion (Fig. 5). Subsequent exposure to hyposmotic medium $(220 \mathrm{mOsm} / \mathrm{kg})$ for $1 \mathrm{hr}$ resulted in a transient stimulation of PRL re- 

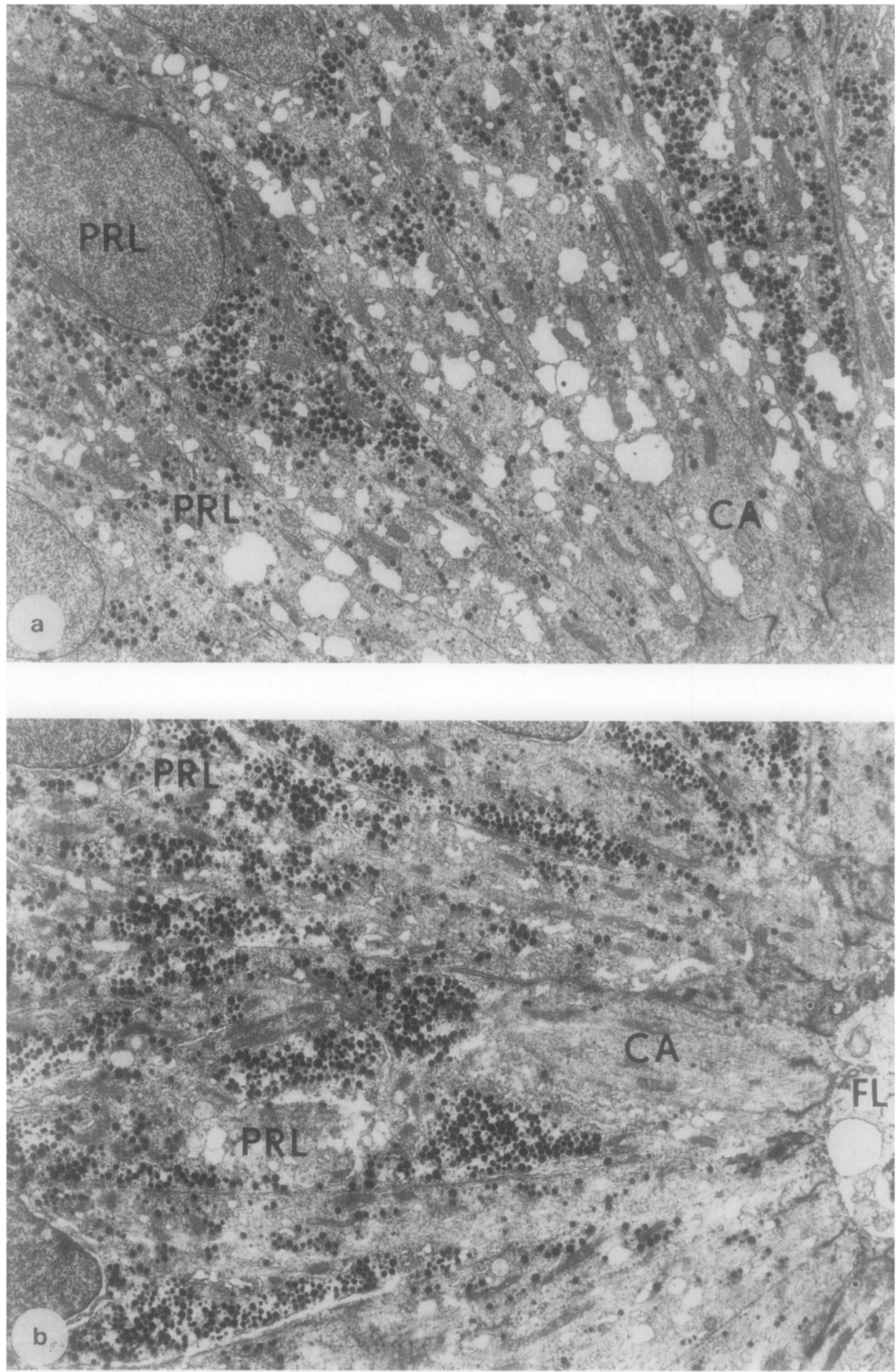

FIG. 2. Electron micrographs of prolactin cells before (a) and $7 \mathrm{hr}$ after (b) perifusion. No major differences were observed between perifused and control groups. PRL, prolactin cell; CA, cellular apex; FL, follicular lumen. 


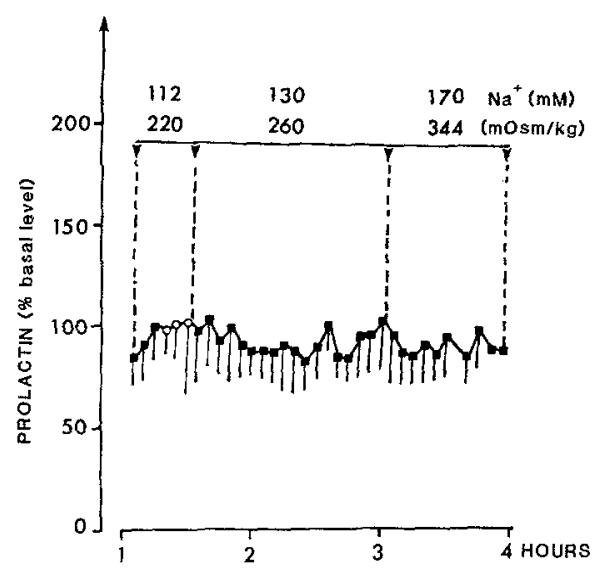

FIG. 3. Effect of stepwise increases in $\mathrm{Na}^{+}$concentration from $112 \mathrm{~m} M(220 \mathrm{mOsm} / \mathrm{kg})$ to $130 \mathrm{mM}(260$ $\mathrm{mOsm} / \mathrm{kg}$ ) and then to $170 \mathrm{~m} M(344 \mathrm{mOsm} / \mathrm{kg})$ on PRL release by perifused trout rostral pars distalis. The basal level (100\% value), $34.6 \pm 6.6 \mathrm{ng} / \mathrm{ml}$, was calculated for each experiment as the mean for three samples $(O)$ just preceding the first change in osmotic pressure in each experiment.

lease $(90 \pm 13.8 \%)$ with a progressive return to basal levels (Fig. 5). During the last hour of perifusion with isotonic medium, a tendency toward a decrease in hormone release was observed. To determine whether the effect on PRL response was due to ionic composition or osmotic pressure, a similar experiment was designed in which osmotic pressure was altered by adding appropriate amounts of mannitol in the presence of a constant $\mathrm{NaCl}$ concentration $(112 \mathrm{mM})$. In this case, PRL release varied in the same

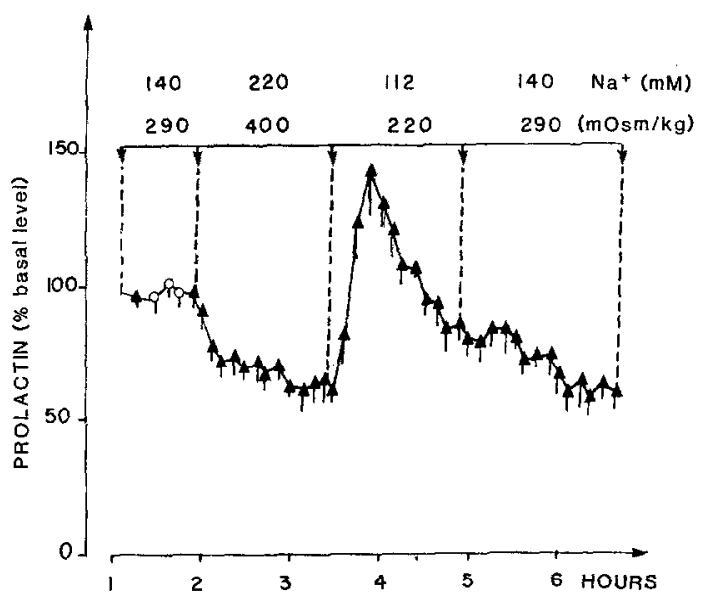

FIG. 5. Effect of sequential changes in sodium concentration on PRL release by perifused trout rostral pars distalis. The basal level (100\% value) was $4.9 \pm$ $0.4 \mathrm{ng} / \mathrm{ml}$. See legend to Fig. 3 for other details.

manner as in the previous experiment (Fig. 6).

The necessity of applying high-amplitude variations of osmotic pressure to obtain an effect on PRL release from perifused pituitary fragments led us to raise further questions about this effect. We therefore investigated the possibility that in the previous experiments, the changes in PRL release may have been due to osmotic shock rather than to an absolute value of osmotic pressure (hyper- vs hyposmotic medium). In a first series of experiments, we compared the effect of different abrupt decreases in osmotic pressure on PRL release; when os-

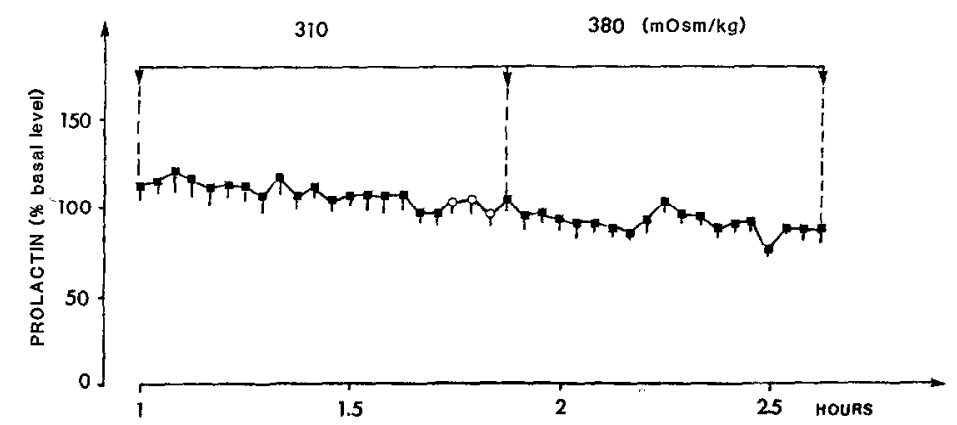

FIG. 4. Effect of $160 \mathrm{mM}(310 \mathrm{mOsm} / \mathrm{kg})$ and $200 \mathrm{mM}(380 \mathrm{mOsm} / \mathrm{kg}) \mathrm{Na}^{+}$on PRL release by perifused trout rostral pars distalis. The basal level $(100 \%$ value $)$ was $3.9 \pm 0.3 \mathrm{ng} / \mathrm{ml}$. See legend to Fig. 3 for other details. 


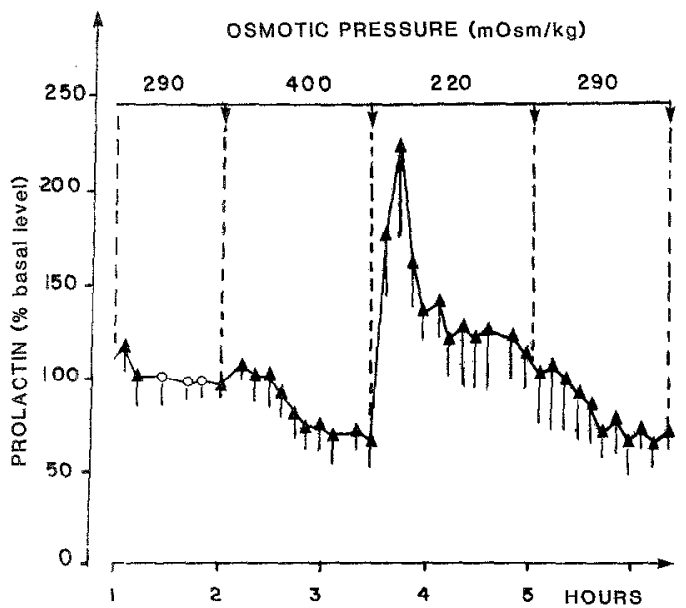

Fig. 6. Effect of hyperosmotic $(400 \mathrm{mOsm} / \mathrm{kg})$ and hyposmotic $(220 \mathrm{mOsm} / \mathrm{kg})$ media with constant sodium concentration on PRL release. Osmotic pressure was modified by adding different mannitol concentrations. The basal level ( $100 \%$ value) was $12.6 \pm 2.6$ $\mathrm{ng} / \mathrm{ml}$. See legend to Fig. 3 for other details.

motic pressure was decreased from 300 to $220 \mathrm{mOsm} / \mathrm{kg}$ (Fig. 7) or from 400 to 300 $\mathrm{mOsm} / \mathrm{kg}$ (Fig, 8), we observed the same pattern of PRL release, i.e., an immediate surge followed by a progressive decrease to basal level.

In a second series of experiments, we examined the response of a second pituitary hormone whose secretion could have been

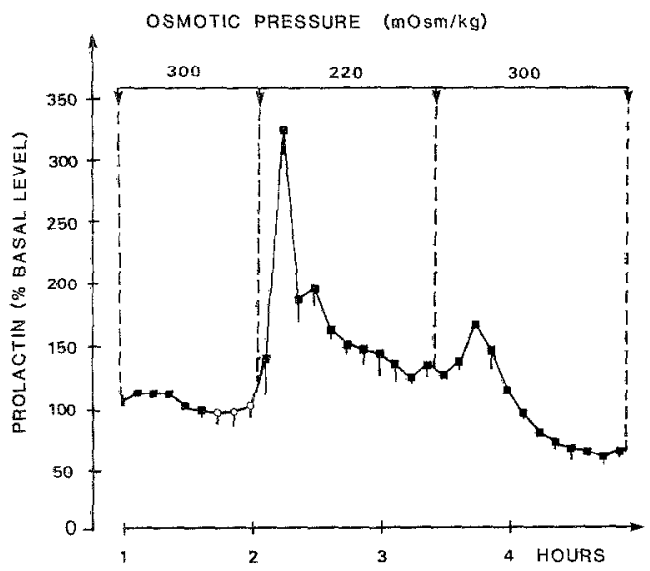

Fig. 7. Effect of hyposmotic $(220 \mathrm{mOsm} / \mathrm{kg})$ and isosmotic ( $300 \mathrm{mOsm} / \mathrm{kg}$ ) media with constant sodium concentration on PRL release. Osmotic pressure was modified by adding different mannitol concentrations. The basal level $(100 \%$ value) was $17.1 \pm 1.1 \mathrm{ng} / \mathrm{ml}$. See legend to Fig. 3 for other details.

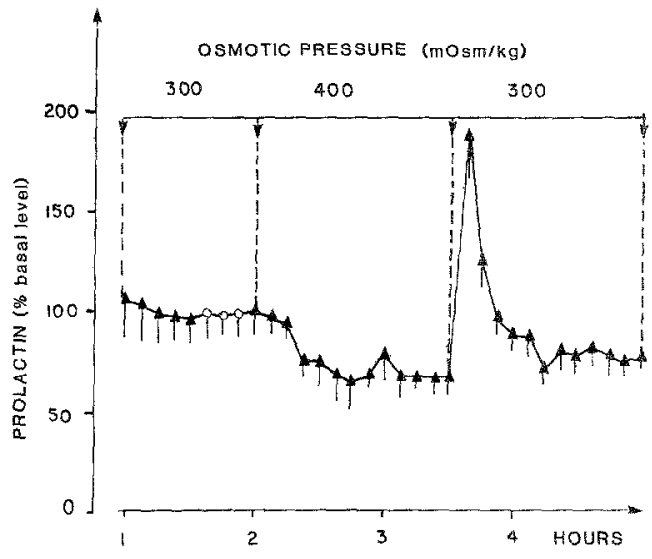

FIG. 8. Effect of hyperosmotic $(400 \mathrm{mOsm} / \mathrm{kg})$ and isosmotic $(300 \mathrm{mOsm} / \mathrm{kg})$ media with constant sodium concentration on PRL release. Osmotic pressure was modified by adding different mannitol concentrations. The basal level ( $100 \%$ value) was $12.3 \pm 4.2 \mathrm{ng} / \mathrm{ml}$. See legend to Fig. 3 for other details.

modified by these osmotic abrupt changes; as shown in Fig. 9, exposure to hyperosmotic medium followed by hyposmotic medium resulted in changes in $\mathrm{GtH}$ release similar to that observed with PRL using the same protocol (Fig. 6). In the same way, an abrupt decrease in osmotic pressure from 400 to $300 \mathrm{mOsm} / \mathrm{kg}$ induced a surge in $\mathrm{GtH}$ release (Fig. 10) closely resembling that obtained with PRL (Fig. 8).

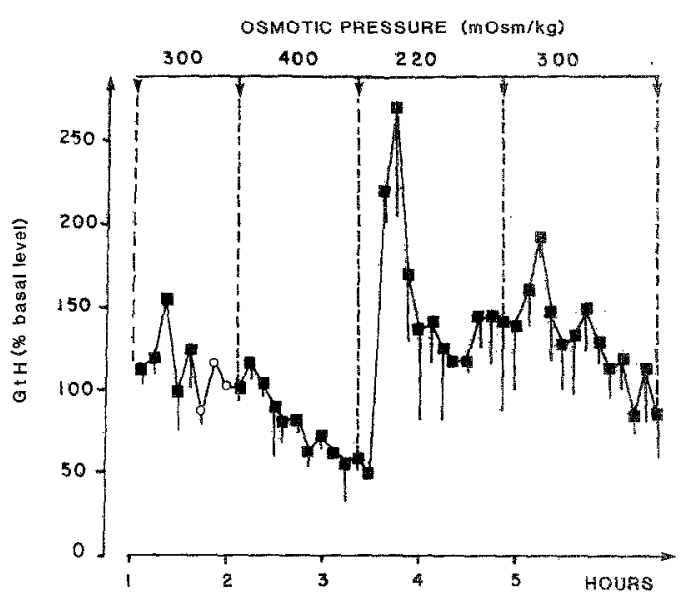

FIG. 9. Effect of sequential changes in sodium concentration on $\mathrm{GtH}$ release by perifused trout proximal pars distalis. The basal level ( $100 \%$ value) was $2.8 \pm$ $0.3 \mathrm{ng} / \mathrm{ml}$. See legend to Fig. 3 for other details. 


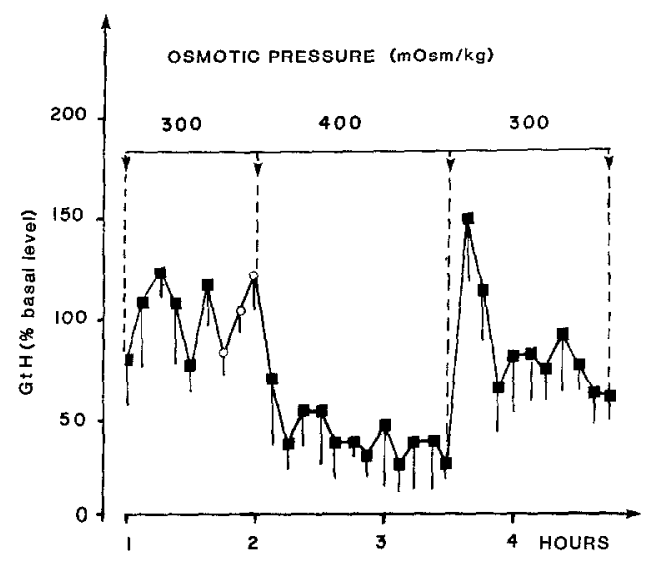

FiG. 10. Effect of hyperosmotic $(400 \mathrm{mOsm} / \mathrm{kg})$ and isosmotic ( $300 \mathrm{mOsm} / \mathrm{kg})$ media with constant sodium concentration on $\mathrm{GtH}$ release. Osmotic pressure was modified by adding different mannitol concentrations. The basal level (100\% value) was $2.4 \pm 0.8 \mathrm{ng} / \mathrm{ml}$. See legend to Fig. 3 for other details.

\section{DISCUSSION}

The in vitro perifusion system described in this paper appears to behave in most respects as would be expected for pituitary hormone secretion. During the first hour of perifusion, a sharp decrease in PRL release was observed, reflecting elimination of PRL that accumulated in the medium before application of pituitary fragments to the column and/or originated from some cell damage during dissection of the pituitary tissue. In all experiments, PRL secretion reached its basal level within $1 \mathrm{hr}$ and remained stable for $6 \mathrm{hr}$ (Fig. 1). This basal level may differ from one perifusion to another but in all cases it was high enough $(>2$ $\mathrm{ng} / \mathrm{ml}$ ) to be detected by our radioimmunoassay technique (sensitivity threshold: 0.4 $\mathrm{ng} / \mathrm{ml}$ ). That the perifused pituitary fragments continued to secrete PRL at a constant rate during perifusion and that the tissue still contained consistent amounts of PRL at the end of the perifusion argue in favor of the continued functioning and viability of pituitaries in our perifusion model. This was confirmed by ultrastructural analysis of perifused tissue which did not reveal any major differences from control pituitaries; after a 6-hr perifusion the appearance of PRL cells and the follicular arrangement were maintained (Fig. 2). Thus, this perifusion technique, associated with a specific RIA for measurement of salmonid PRL, appears to be a useful tool for studying, in rainbow trout, the dynamics of pituitary PRL secretion and its possible control by osmotic pressure.

The present investigation, using this perifusion technique, clearly shows that a gradual increase in osmotic pressure does not induce significant modification of PRL release (Figs. 3 and 4). For these experiments, the osmotic pressures were selected to parallel physiological values measured in the plasma of SW- and FW-adapted rainbow trout (Conte and Wagner, 1965; Bath and Eddy, 1979; Eddy, 1982; Boeuf and Harache, 1984; Prunet and Boeuf, 1985). These results are in agreement with other in vitro studies. For instance, Baker and Ingleton (1975), using incubated rainbow trout pituitaries, did not observe any changes in PRL release; however, the technique (polyacrylamide gel electrophoresis at $\mathrm{pH}$ 9.5) used by these authors for measuring PRL content may not have been an adequate tool for analyzing trout PRL if this hormone is a basic protein as is salmon PRL (Kawauchi el al., 1983; Prunet and Houdebine, 1984). Recently, Suzuki et al. (1987) did not observe a significant stimulatory effect of hypotonic medium on PRL release from incubated chum salmon pituitaries. The present findings with rainbow trout differ notably from other studies on the effect of osmotic pressure on PRL release; similar in vitro studies with other teleosts testing a range of osmotic pressures led to marked modification of PRL secretion (e.g., Nagahama et al., 1975; Wigham et al., 1977; Grau et al., 1981). Moreover, recent studies using perifused tilapia rostral pars distalis confirmed that reduced osmotic pressure $(280 \mathrm{mOsm} / \mathrm{kg})$ stimulates release of PRL, while hyperosmotic medium (355 $\mathrm{mOsm} / \mathrm{kg}$ ) reduces it. This observed effect is rapid and lasts for at least 2 to $3 \mathrm{hr}$ (Grau et al., 1986, 1987). The reason for 
such a discrepancy is not clear but may be related to species differences. In any case, it appears that the rainbow trout differs notably in the lack of sensitivity of its PRL cells to osmotic pressure from nonsalmonid teleost species studied so far.

Application of higher variations of osmotic pressure resulted in clear modification of PRL secretion; while an increase from 300 to $400 \mathrm{mOsm} / \mathrm{kg}$ decreased PRL release, a subsequent decrease of osmotic pressure from 400 to $220 \mathrm{mOsm} / \mathrm{kg}$ increased it (Fig. 5). This effect was due to osmotic pressure itself rather than changes in $\mathrm{NaCl}$ concentrations, as experiments with mannitol concentrations gave similar patterns of PRL release (Fig. 6). The levels of osmotic pressure used in these experiments appeared to be at the limit of the physiological range observed in rainbow trout, although values as high as $400 \mathrm{mOsm} /$ $\mathrm{kg}$ have been recorded in fish 3 days following direct transfer from $\mathrm{FW}$ to SW (Prunet et al., 1985). Thus, the need for large osmotic pressure variations to modify PRL release could be due to a low sensitivity of PRI . cells to osmotic pressure in rainbow trout. It is also possible that these large variations induced osmotic shock, resulting in changes in hormonal release. Experiments designed to answer this last problem clearly showed that the PRL secretion surge obtained after exposure to 300 to 220 $\mathrm{mOsm} / \mathrm{kg}$ was also observed when osmotic pressure was decreased from 400 to 300 $\mathrm{mOsm} / \mathrm{kg}$. It appears therefore that the induced change in PRL secretion is likely due to the magnitude of the change in osmotic pressure and not to the hyposmotic medium. In mammals, release of pituitary hormones from incubated bovine glands can be modified by alteration of the osmolarity of the medium to $10 \%$ above the control (Labella et al., 1975). In particular, LH release from adenohypophyseal cells is inversely related to extracellular osmolarity (Greer et al., 1985). The latter authors suggested that the effects observed were attributable to a mechanical effect of the osmotic pressure, which may alter the cell volume and induce an expansion or a contraction of the outer cell membrane. We thus assume that a similar phenomenon may explain, in our experiment, the in vitro effects of a large variation in osmotic pressure on PRL release. Such a hypothesis would imply that these effects should not be specific to one particular hormone. By measuring GTH release in two series of perifusion experiments, we found parallel changes in GTH release and in PRL release.

In conclusion, we found that rainbow trout differ notably from other teleost fish in the control of PRL release and in its sensitivity to osmotic pressure. During the first 3 days following transfer from FW to SW or the converse, changes in plasma osmotic pressure may be sufficient to induce physiological modifications of PRL secretion (Prunet and Boeuf, 1985; Prunet et al., 1985; Hirano et al., 1985; Suzuki et al., 1987). The origin of such regulation should be at the level of the central nervous system; the effects of external medium changes on hypothalamic neurohormone secretion require investigations.

\section{ACKNOWLEDGMENTS}

We thank Professor H. A. Bern and Dr. J. P. Bolton for critical review and discussion of the manuscript and $O$. Metarfi for excellent secretarial assistance.

\section{REFERENCES}

Abraham, M. (1971). The ultrastructure of the cell types and the neurosecretory innervation in the pituitary of Mugil cephalus L. from fresh water, the sea, and a hypersaline lagoon. I. The rostral pars distalis. Gen. Comp. Endocrinol. 17, 334 350 .

Baker, B. I., and Ingleton, P. M. (1975). Secretion of prolactin and growth hormone by teleost pituitaries in vitro. II. Effect of salt concentration during long term organ culture. J. Comp. Physiol. 100, 269-282.

Ball, J. N. (1981). Hypothalamic control of the parts 
distalis in fishes, amphibians, and reptiles. Gen. Comp. Endocrinol. 44, 135-170.

Bath, R. N., and Eddy, F. B. (1979). Salt and water balance in rainbow trout (Salmo gairdneri) rapidly transferred from fresh water to sea water. J. Exp. Biol. 93, 193-202.

Batten, T. F. C., Young, G., and Ball, J. N. (1983). Secretory activity of Poecilia latipinna (Teleotei) pituitary in vitro: Rostral pars distalis and proximal pars distalis. Gen. Comp. Endocrinol. 51, 113-130:

Bern, H. A. (1983). Functional evolution of prolactin and growth hormone in lower vertebrates. Amer. Zool. 23, 663-671.

Boeuf, G., and Harache, Y. (1984). Adaptation osmotique à l'eau de mer de différentes espèces (Salmo trutta, Salmo gairdneri, Salvelinus fontinalis) et hybride (Salmo trutta $\times$ Salvelinus fontinalis) de salmonidés. Aquaculture 40, 343-358.

Breton, B., Prunct, P., and Rcinaud, P. (1978). Sexual differences in salmon gonadotropin. Ann. Biol. Anim. Biochim. Biophys. 18, 759-765.

Clarke, W. C., and Bern, H. $\Lambda$. (1980). Comparative endocrinology of prolactin. In "Hormonal Proteins and Peptides" (C. H. Li, Ed.), Vol. 8, pp. 105-197. Academic Press, New York.

Conte, F. P., and Wagner, H. H. (1965). Development of osmotic and ionic regulation in juvenile steelhead trout Salmo gairdneri. Comp. Biochem. Physiol. 14, 603-620.

Cook, H., and Van Overbeeke, A. P. (1969). Ultrastructure of the eta cells in the pituitary gland of adult migratory sockeye salmon (Oncorhynchus nerka). Canad. J. Zool. 47, 937-941.

Dharmamba, M., and Nishioka, R. S. (1968). Response of "prolactin secreting" cells of Tilapia mossambica to environmental salinity. Gen. Comp. Endocrinol. 10, 409-420.

Dubourg, P., Chambolle, P., Kah, O., Maiza, S., and Olivereau, M. (1983). Ultrastructure des cellules à prolactine et survie de Gambusia sp. (poisson téléostéen) en eau désionisée enrichie en calcium ou en sodium. Gen. Comp. Endocrinol. 50, 432-444.

Dubourg, P., Chambolle, P., Olivereau, M., and Kah, O. (1980). Ultrastructure des cellules à prolactine de Gambusia sp. (poisson téléostéen) en eau douce, en eau désionisée et en milieu hypersalin. Gen. Comp. Endocrinol. 41, 554-562.

Eddy, F. B. (1982). Osmotic and ionic regulation in captive fish with particular reference to salmonids. Comp. Biochem. Physiol. B 73, 125-141.

Grau, E. G., Ford, C. A., Helms, L. M. H., Shimoda, S. K., and Cooke, I. M. (1987). Somatostatin and altered medium osmotic pressure elicit rapid changes in prolactin release from the rostral pars distalis of tilapia, Oreochromis mossambicus, in vitro. Gen. Comp. Endocrinol. 65, 12-18.
Grau, E. G., Nishioka, R. S., and Bern, H. A. (1981). Effects of osmotic pressure and calcium ion on prolactin release in vitro from the rostral pars distalis of the tilapia, Sarotherodon mossambicus. Gen. Comp. Endocrinol. 45, 406-408.

Grau, E. G., Shimoda, S. K., Ford, C. A., Helms, L. M. H., Cooke, I. M., and Pang, P. K. T. (1986). The role of calcium in prolactin release from the pituitary of teleost fish in vitro. Endocrinology 119, 2848-2855.

Greer, M. A., Greer, S. E., Opsahl, Z., and Maruta, S. (1985). Comparison of hyposmolar and hyperosmolar. Effect on in vitro luteinizing hormone secretion by anterior pituitary cells. Proc. Soc. Exp. Biol. Med. 178, 24-28.

Hirano, T. (1986). The spectrum of prolactin action in teleosts. In "Comparative Endocrinolugy: Developments and Directions" (C. L. Ralph, Ed.), pp. 53-74. Alan Liss, New York.

Hirano, T., Prunet, P., Kawauchi, H., Takahaski, A., Kubota, J., Nishioka, R. S., Bern, H. A., Takada, K., and Ishii, S. (1985). Development and validation of a salmon prolactin radioimmunoassay. Gen. Comp. Endocrinol. 59, 266-276.

Ingleton, P. M., Baker, B. I., and Ball, J. N. (1973). Secretion of prolactin and growth hormone by teleost pituitaries in vitro. I. Effect of sodium concentration and osmotic pressure during short term incubations. J. Comp. Physiol. 87, 317-328.

Kawauchi, H., Abe, K., Takahashi, A., Hirano, T., Hasegawa, S., Naito, N., and Nakai, Y. (1983). Isolation and properties of chum salmon prolactin. Gen. Comp. Endocrinol. 49, 446-458.

Labella, F., Dular, R., Queen, G., and Vivian, S. (1975). Anterior pituitary hormone release in vitro inversely related to extracellular osmolarity. Endocrinology 96, 1559-1565.

I.eatherland, J. F., and Fnsor, D. M. (1973). Activity of autotransplanted pituitary glands in goldfish, Carassius auratus L., maintained in different ambient salinities. Canad. J. Zool. 51, 225-235.

Leatherland, J. F., and Lin, L. (1975). Activity of the pituitary gland in embryo and larval stages of coho salmon, Oncorhynchus kisutch. Canad. J. Zool. 53, 297-310.

Leatherland, J. F., and McKeown, B. A. (1974). Effect of ambient salinity on prolactin and growth hormone secretion and on hydromineral regulation in Kokanee salmon smolts (Oncorhynchus nerka). J. Comp. Physiol. 89, 215-226.

McKeown, B. A., and Leatherland, J. F. (1973). Fine structure of the adenohypophysis in immature sockeye salmon, Oncorhynchus nerka. Z. Zellforsch. 140, 459-471.

Nagahama, Y., Clarke, W. C., and Hoar, W. S. (1977). Influence of salinity on ultrastructure of the secretory cells of the adenohypophyseal pars 
distalis in yearling coho salmon (Oncorhynchus kisutch). Canad. J. Zool. 55, 183-198.

Nagahama, Y., Nishioka, R. S., and Bern, H. A. (1973). Responses of prolactin cells of two euryhaline marine fishes, Gillichthys mirabilis and Platichthys stellatus to environmental salinity. $Z$. Zellforsch. 136, 153-157.

Nagahama, Y., Nishioka, R. S., and Bern, H. A. (1974). Structure and function of the transplanted pituitary in the sea water goby, Gillichthys mirabilis. 1. The rostral pars distalis. Gen. Comp. Endocrinol. 22, $21-34$.

Nagahama, Y., Nishioka, R. S., Bern, H. A., and Gunther, R. L. (1975). Control of prolactin secretion in teleosts, with special reference to Gillichthys mirabilis and Tilapia mossambica. Gen. Comp. Endocrinol. 25, 166-168.

Olivereau, M., Chambolle, P., and Dubourg, P. (1981). Ultrastructure of prolactin cells in the eel kept in fresh water, deionized water and normal and concentrated sea water. Biol. cell. 42, 153-166.

Prunet, P., and Bocuf, G. (1985). Plasma prolactin level during transfer of rainbow trout (Salmo gairdneri) and Atlantic salmon (Salmo salar) from fresh water to sea water. Aquaculture 45, 167 . 176.

Prunet, P., Boeuf, G., and Houdebine, L. M. (1985). Plasma pituitary prolactin levels in rainbow trout during adaptation to different salinities. J. Exp. Zool. 235, 187-196.

Prunet, P., and Houdebine, L. M. (1984). Purification and biological characterization of chinook salmon prolactin. Gen. Comp. Endocrinol. 53, 49.57.

Specker, J. L., Ingleton, P. M., and Bern, H. A. (1984). Comparative physiology of the prolactin cell. In "Frontiers and Perspectives in Prolactin Secretion: A Multidisciplinary Approach" (F. Mena and C. M. Valverde, Eds.), pp. 17-30. Academic Press, New York.

Suzuki, R., Kishida, M.. Ogasawara, T., Hasegawa, S., and Hirano, T. (1987). Prolactin and growth hormone secretion during long-term incubation of pituitary pars distalis of mature chum salmon, on corhynchus keta. Submitted for publication.

Tonon, M. C., Leroux, P., Leboulenger, F., Delarue, C., Jegou, S., and Vaudry, H. (1980). Thyrotropin-releasing hormone stimulates the release of melatropin from frog neurointermediate lobe in vitro. Life Sci. 26, 869-875.

Wendelaar Bonga, S. E., Flik, G., Lowik, C. W. G., and Van Eys, G. J. J. M. (1985). Environmental control of prolactin synthesis in the teleost fish Oreochromis (formerly Sarotherodon) mossambicus. Gen. Comp. Endocrinol. 57, 352-359.

Wendelaar Bonga, S. E.. and Van der Meij, J. C. A. (1980). The effect of ambient calcium on prolactin cell activity and plasma electrolytes in Sarotherodon mossambicus (Tilapia mossambica). Gen. Comp. Endocrinol. 40, 391-401.

Wigham, T., Nishioka, R. S., and Bern, H. A. (1977). Factors affecting in vitro activity of prolactin cells in the euryhaline teleost Sarotherodon mossambicus (Tilapia mossambica). Gen. Comp. Endocrinol. 32, 120-131. 